\title{
Micah 7:8-20: An apt conclusion to the book of Micah
}

\author{
W J Wessels \\ (University of South Africa)
}

\section{ABSTRACT}

\section{Micah 7:8-20: An apt conclusion to the book of Micah}

It is argued in this article that Micah 7:8-20 forms an apt conclusion to the book of Micah. As was the case with Micah 1, the concluding section also focusses on Yahweh and his dealings with the people of the earth. There is a universal tendency to be detected in this section as well. An important aspect to notice is the liturgical nature of chapters six and seven, especially 7:8-20. There is a vagueness, almost a timelessness, imbuing this section. This could be intended allowing later generations of believers to apply these words to their own circumstances. With Micah 7:8-20 as the concluding section of the book, one is left with a sense of well-roundedness, of completeness. The collection of oracles attributed to Micah in general has a sombre tone. For this very reason Micah 7:8-20 seems to change the mood. It breathes hope into a negative atmosphere of judgment. It ends with a strong emphasis on the power of Yahweh, the power of forgiveness.

\section{INTRODUCTION}

Micah 7:8-20 seems to be an apt conclusion to the book of Micah for several reasons. From a study of this book it seems quite clear that the book of Micah is a collection of prophetic oracles. They were most probably collected over a period of time by people, or a group of people, who felt a particular need to conserve the sayings of the prophet Micah, or sayings which related closely to what the prophet had in mind. One cannot assume with any certainty that all the oracles originated with the prophet named Micah, but to deny him these oracles also can not be done with a great deal of certainty. It is therefore perhaps wise to read the oracles as a collection and try to come to grips with the form and structure in which it is presented to us. There will always be some uncertainty with any endeavour to explain the organisation, structure and authorship of the book. But this should not inhibit us to read the text with a sense of curiosity and creativity, to search for meaning and propose possible readings.

Some years ago (1998) I suggested that for a great deal the book of Micah concerns power and the abuse of power. Back then it seemed to me that Micah 1 forms an apt introduction to the comments on power which follow this chapter. The reason was that chapter one commences 
with an universal call to all the people of the earth to take notice of Yahweh who is the Sovereign Power everyone should acknowledge. When reading the closing part of Micah, it dawned on me that once again the focus is on Yahweh who has no comparison, as well as on the people of the earth who would be witnesses to this fact. This gives rise to the idea of the title of Micah 7:8-20 as an apt conclusion to the book of Micah.

It is also clear from the study of chapters six and seven of Micah that there are strong liturgical overtones to be detected. There are several reasons why this seems to be the case. One such reason would be that in worship lies the true heart of dedication to Yahweh and allows worshippers the best possible opportunity of expressing their intimate relationship with Him. It can also be that the altar is the proper place to do penance as well as to renew one's relationship with the covenantal God. All of this may be true concerning the intended audience of the oracles in the book of Micah, but the character of the liturgical sayings in Micah also seem to be of a more universal and neutral nature. This would have had the benefit that people over generations could have identified with these sayings as part of their expression of faith in Yahweh (cf Andersen \& Freedman 2000:600). Micah 7:8-20 again appeals to peoples of the world to acknowledge Yahweh and worship him. He is an incomparable God.

\section{A CLOSER LOOK AT MICAH 7:8-20}

Micah 7:8-20 is regarded as an unit, although it can be subdivided into smaller units as well. This unit forms the closing section of the book of Micah. It is, however, important to look at this unit within the context of the collection of oracles in the book.

\subsection{Micah 7:8-20 within the context of the book of Micah}

The book of Micah can in broad terms be divided into two sections, namely chapters 1-5 and 6-7. The section 6:1-7:7 deals with different areas of a person's life and shows that all areas of life concern Yahweh. This should not be regarded as a categorisation of one's existence in separate compartments, but a matter of focus. In $6: 1-8$ the focus is on the requirements regarding general attitude and worship. This is followed by verses 9-16 referring to everyday conduct, especially in the area of trade and commerce. The third area is that of the public and private life (7:17). No area of life escapes God's attention and people who claim to belong to him should realise this. The book is concluded with $7: 8-20$, the section under discussion. 


\subsection{Structure and exposition of Micah 7:8-20}

It is suggested that these last verses in the book of Micah form a suitable closure to the book. It addresses several of the themes that occurred in some of the oracles throughout the book. There are references to the sinful nature of society (v9); the role of the nations in causing the people of God to suffer (v10); hope for the restoration of the people and the land (v11), and the shepherd-king theme (v14). Many scholars regard 7:8-20 as a late addition to the book, which is a possibility (cf Mays 1976:154). Alfaro (1989:77) for instance maintains that the period after the Babylonian Captivity offers a perfect setting for this section, but at the same time leaves room for those who think in terms of the fall of Samaria or the partial destruction of Jerusalem before the exile of 586 $\mathrm{BCE}$, as possibilities. Others again think that it ties in well with the general trend of the prophet Micah's thinking (cf Hillers 1984: 89-90). Shaw (1993:198-200) discusses the different arguments presented for dating this section, and then concludes that one should probably favour the time and conditions of Micah for this poem. He holds this view in light of the fact that the evidence at hand leaves room for more than one interpretation and that no strong evidence is presented to dismiss the claim for Micah's time. How this final collection came about cannot be determined, but it leaves the audience and the reader with a sense of a well-rounded completeness.

Verses $8-20$ as a unit shows a strong resemblance to many of the psalms in the Old Testament (cf Pss $12 ; 27: 1-6 ; 44 ; 50 ; 62 ; 75 ; 77 ; 80$; $81 ; 82 ; 90 ; 95$ ) and is referred to as a prophetic liturgy (cf Hillers 1984:89; also Gowan 1998:57). McKane (1998:21) however says we can say nothing than that “...7:8-20 were psalms which served as congregational responses and are pointers to a liturgical use of the book Micah". The liturgical or confessional nature would perhaps explain the lack of clear references to the defeat envisaged; the identity of the enemy; the walls which are to be rebuilt; the boundaries which would be expanded and the return of the people. There is a vagueness, almost a timelessness, imbuing this section. This could be intended allowing later generations of believers to apply these words to their own circumstances. There is also a sense of reminiscing in this section (cf v14 "...as in days of old"; v20: "...from days of old") which further supports the idea of its confessional nature.

Chapter 7:8-20 reflects some of the facets which are typical of the genre of a lament. These components are: an expression of confidence (vv8-10); a divine oracle (vv11-13); a prayer for restoration (vv14-17) and an offering of praise (vv18-20; Gerstenberger 1977:200). However, it is not important to decide whether this is a proper lament or an imita- 
tion of the form of a lament, for the purpose is clear. Yahweh will take care of his people and their future. Micah 7:8-20 is presented as a unit, composed of different subsections as already indicated.

\section{Verses 8-10: Acknowledgment and trust}

${ }^{8}$ Do not gloat over me, my enemy! ${ }^{1}$

Though I have fallen, I will rise.

Though I sit in darkness,

the LORD will be my light.

${ }^{9}$ Because I have sinned against him,

I will bear the LORD's wrath,

until he pleads my case

and establishes my right.

He will bring me out into the light;

I will see his righteousness.

${ }^{10}$ Then my enemy will see it

and will be covered with shame,

she who said to me,

"Where is the LORD your God?"

My eyes will see her downfall;

even now she will be trampled underfoot

like mire in the streets.

As was indicated, the initial element of the lament is to express confidence that Yahweh will come to their rescue in spite of their transgressions and prevailing misery.

Verse 8 describes a situation where the speaker admits defeat. It is not clear what should be understood by this, but it probably refers to military defeat by an enemy. The speaker, probably Jerusalem representing the afflicted community, addresses with an expression of confidence the enemy who is rejoicing in the misery of the people of Judah. The speaker acknowledges that they are in a desperate state, a situation of darkness, but this is only temporary. They have somebody who will take care of them, who will bring light to their darkness, who will restore them and give them back their dignity- Yahweh will come to their rescue.

In verse 9 this corporate personality (representative) for a moment turns his eyes away from the enemy to the self, acknowledging responsibility for the current state of affairs. What they experience is due to the wrath of Yahweh and has been caused by their sin against him. No one is

1 The New International Version, (Grand Rapids, MI: Zondervan Publishing House) 1984. 
to blame for it, except themselves, and they acknowledge this. Using the imagery of the court of law, the speaker awaits both the plea, bargaining on their behalf, and also fair judgement by the divine Judge. This will bring light in their state of darkness, a situation of forgiveness and restoration for Yahweh's people, demonstrating his righteous deeds by taking up the case with the enemy on behalf of his people and for his own honour. Deliverance from their enemy is imminent.

Verse 10. The enemy reacted boastfully towards the people of God, mocking them with the question: "Where is your God?" They are a defeated people, a pitiful people, for even their God has deserted them. The enemy regarded their victory over Judah as a victory over the God they confess as well. The enemy looked upon the people of God with contempt, "their eyes" gloating over the city and its inhabitants. But the speaker is confident that Yahweh will have the final say in matters. The enemy will be put to shame when he acts on behalf of his people, for they will be totally demolished, trodden down like mud in the streets. Yahweh will humiliate this enemy. They confess that he is their source of hope for deliverance and their future. His dynamic presence brings light and hope.

\section{Verses 11-13: Divine providence}

${ }^{11}$ The day for building your walls will come, the day for extending your boundaries.

${ }^{12}$ In that day people will come to you

from Assyria and the cities of Egypt, even from Egypt to the Euphrates

and from sea to sea

and from mountain to mountain.

${ }^{13}$ The earth will become desolate because of its inhabitants, as the result of their deeds.

Acknowledgement and confession of $\sin$ is followed by divine promises. The next three verses are an oracle of salvation to the people of God and have an eschatological perspective. The speaker of the previous section now becomes the addressee of this divine oracle. These futuristic and hopeful promises would very well suit a liturgical setting for these last verses. It serves the purpose of affirming God's involvement in their future and it expresses their hope in him for restoration. Thus these would be the words of a community of believers, who confess their faith in him who holds the future.

In verse 11 the prophet, as mouthpiece of Yahweh, announces a favourable day for his people. This refers to a situation of destruction and loss that needs to be reconstructed and restored. It will be a day of 
the rebuilding of walls. Although the word used here for walls is not the term usually describing the walls of a city, the image is one of restoration which could also include the walls of the city. Hillers (1984:89) regards the word for "walls" as unusual and says the sense could be metaphorical or general ("the nation's walls"; cf Psalm 89:41 which refers to city walls using the same Hebrew word). This day will also include the expansion of the boundaries of the country, perhaps a revitalization of the ideal times of the reign of David, when Israel was considered a force among nations. ${ }^{2}$

Verse 12. The day of salvation will also include a flocking of people to Jerusalem. Usually this statement is regarded to be a reference to the nations coming to Zion, but it could indicate the people of Israel and Judah, scattered all over the world due to enemy activity (Is 11:1112 is important in this regard). They will come from places that stretch from Assyria to Egypt, from Egypt to the Euphrates ${ }^{3}$, from sea to sea, from mountain to mountain. The function of the geographical references is to emphasize the variety of people who will come to Jerusalem. This is reminiscent of 4:1-5, which convey the same notion (cf Is $27: 12,13$ ).

Verse 13. In contrast to the city Zion, the earth will become desolate because of the deeds of its inhabitants. Once again emphasising the eschatological perspective, Zion will be like an oasis in a desolate land. Its people will be safe amidst a desolate world. Justice to Judah will entail judgement meted out to the peoples of the earth (cf Jl 3:18-21; Ob vv 15-17; Is 24-26).

Once again these divine oracles strengthen the sense of hope and a future to the people of Judah. It also communicates that Yahweh cares for those who are his people and realise that he holds the future.

\section{Verses 14-17: Shepherd your people!}

${ }^{14}$ Shepherd your people with your staff,

the flock of your inheritance,

which lives by itself in a forest,

in fertile pasturelands.

Let them feed in Bashan and Gilead

as in days long ago.

15 "As in the days when you came out of Egypt,

I will show them my wonders."

${ }^{16}$ Nations will see and be ashamed,

2 Some translations prefer the meaning "decree" to "boundary" and therefore offer the following translation: "A day of the removal of the decree".

3 Cf Gn 15:18; also Ps 80:11, 12 and 13 which refers to mountains, sea, Euphrates and walls (v 11) of a vineyard. 
deprived of all their power.

They will lay their hands on their mouths

and their ears will become deaf.

${ }^{17}$ They will lick dust like a snake,

like creatures that crawl on the ground.

They will come trembling out of their dens;

they will turn in fear to the LORD our God

and will be afraid of you.

This subsection is a prayer of supplication to Yahweh by the community (cf Pss 44; 77 and 88), in the present context probably in response to the divine promise of salvation in verses 11-13. Verses 14-15 form the first part of the prayer and concern the people and their history, whilst the second part focuses on the nations (vv16-17).

Verse 14 invokes Yahweh to act as shepherd of his people. This is a familiar image, usually applied to the king as shepherd of his people. In this communal prayer the people acknowledge that God is their king and he is requested to shepherd them as his inheritance. They are linked to him for generations as a people inherited by him. They belong to him, therefore, they now call upon his care, protection and guidance in their time of distress. The people experience their current situation as difficult and lonely, living in a confined area which has become a scrubland. In 3:12 it was announced that Jerusalem would become a hilltop of scrubs (ya'ar). While they had to survive in these restrictive grazing conditions, their environment seems fertile and has ample pastures. They request their shepherd-king to provide, once again, access to such fertile areas as Bashan and Gilead in the days of old (cf Schuman 1989:179). Hillers (1984:90) regards Bashan and Gilead as places with symbolic meaning.

Verse $15^{4}$ continues the reference to the past, which ends in verse 14. Now the Exodus is called to mind and with it the glorious history of God delivering them from oppression and captivity. The emphasis is on God with them throughout this redemptive event (cf "The day when you came out..."). They pray to Yahweh to once again intervene with a saving miracle, similar to the Exodus wonder, and to deliver them from their circumstances of hardship. The call to the history of salvation, characteristic of the lament (cf Pss 44:2-3; 74:2, 12-15; 77:6, 12, 15-21;

4 This is a difficult verse as far as the pronouns are concerned. It reads as follows: "As in the days when you came out from the land of Egypt, I shall cause him to see wonders". Some exegetes follow Wellhausen's suggestion by emending the text to read "let us see..."; cf Hagstrom (1988:101) for a discussion of the difficulties. He opts to keep the Masoretic Text as it is and regards v 14 as a response by Yahweh to the plea of the people in verse 14 . 
80:9-12) serves to affirm their trust in God's ability to act favourably on their behalf.

Verse 16. The focus now in verses 16-17 moves to the nations. These two verses describe the reaction of the nations which are confronted by God when he reveals his wondrous power. Their power will be eclipsed when compared with the power of Yahweh. The nations will see his greatness and be ashamed of the power they have displayed. They are now the victors, but their victory is something to be ashamed of in comparison to what God is about to bring. The believing community confesses this with confidence in prayer, because they can imagine it taking place in the mind's eye. The nations, in disbelief, will cover their mouths with their hands (cf Jdg 18:19; Job 21:5; 29:9; 40:4), speechless and dumb, by what will take place when God miraculously intervenes. In shock they will react as if they are deaf, not wishing to hear about his greatness any longer.

Verse 17 continues the description of what could be expected to happen to the nations who gloated over and mocked the city and its inhabitants. They will become a defeated people who will humble themselves before their victor. Their humiliation is described as a snake licking dust and crawling on the ground, while trembling in fear of Yahweh (cf Is 49:23; Ps 72:9). The prayer of the community is a prayer of faith that God will take care of these nations and ensure their defeat.

\section{Verses 18-20: The Lord our Saviour!}

${ }^{18}$ Who is a God like you, who pardons sin and forgives the transgression

of the remnant of his inheritance?

You do not stay angry forever

but delight to show mercy.

${ }^{19}$ You will again have compassion on us;

you will tread our sins underfoot

and hurl all our iniquities into the depths of the sea.

${ }^{20}$ You will be true to Jacob, and show mercy to Abraham, as you pledged on oath to our fathers in days long ago.

The book concludes with a hymn expressing Yahweh's great kindness and compassionate nature. These verses reveal the very foundation of the community's existence and hope for the future. It is not what they can offer or accomplish, but who he is that will save the day. His nature is described in a fourfold way, followed by another four statements expressing how he will act in ways congruent with his nature. 
Verse 18 begins with a question about the nature of God and the question is immediately answered by asserting that he is a God who forgives. This is most important, for without his forgiveness they have no right to exist. They are a people guilty of sin and beset by transgressions, who time and time again have to hear from the prophet that Yahweh is dissatisfied with their sinfulness and disobedience. His forgiveness is the sole source of their hope for a future. They are the people of God and have become his own inheritance. Moreover, he will see to it that a faithful few survive through grace and forgiveness. His lovingkindness towards his own will avert his anger.

Verse 19 is an affirmation that it is only the repeated revelation of his compassion that saves them from total rejection and destruction. Although their sin is cause for destruction, he will show his love and kindness and act by his grace. He will tread upon their sins and cast the fragments into the sea. This image alludes to an act of deliverance similar to God's salvation from the pursuing Egyptians, when the nation came out of slavery and bondage ( $\operatorname{cf}$ Ex 15:4-5).

Verse 20 confirms God's faithfulness towards his people and that he will honour the commitment he made to Abraham and Jacob in days of old. He will remain their God and they will continue to be his people. This implies hope for the future.

It is clear from the discussion that Micah 7:8-20 deals with the loving and forgiving nature of Yahweh. He is the one who cares for the faithful among his people and restores them. He acts out of loyalty, kindness and forgiveness. Forgiveness is the key in maintaining all relationships. To make retribution, sin needs to be forgiven. The interlocutor in Micah is wise to admit sin; to call on God's grace and forgiveness, to trust him for restoration, and to wait on him to bring light to a situation of darkness. Yahweh will honour those who are ridiculed by enemies because of their confession of faith in him. Human efforts cannot secure the future. Yahweh is not only the Lord of his people, but also of the nations. He is the one who shepherds his people as their king by caring and protecting them.

\section{CONCLUSION}

In the introductory part of this article, the statement was made that Micah 7:8-20 forms an apt conclusion to the book of Micah. The question can be asked whether it was an appropriate supposition. The following reasons in conclusion seems to substantiate the assumption.

As was the case in the first chapter, the book ends with a focus on Yahweh who has no comparison. To quote Andersen \& Freedman (2000:28), "The book begins with a powerful and terrifying revelation of 
God in angry judgment. It ends with an even more overwhelming disclosure of God in love and compassion". He is kind, loving, faithful and most of all a forgiving God. He holds the future of his people. If one again thinks of power, then it is clear that true power is with Yahweh. The strongest form of power revealed in this closing section, is the power of forgiveness. This is the key to restored relationships between Yahweh and his people and the initiative lies with him.

This concluding section however, also deals with the nations as in chapter one. They will according to Micah, come to realise that Yahweh is the true God who cares and protects his people. His nature and power will affect all peoples of the earth. This gives, as in the beginning, an universal character to the book. Yahweh's actions concerns the people of the world.

The liturgical nature of chapters six and seven, but especially $7: 8$ 20 ties in with the universal tendency in the book of Micah. The more neutral and non-specific tendency of the sayings in this last section as discussed seems to enhance this universal tendency. It forms an apt conclusion to the book of Micah because it tends to draw believers over centuries in to participate in the celebration of a history of salvation. By identifying with these sayings about Yahweh, believers confirm their personal experience of salvation as a result of Yahweh's faithfulness.

As was mentioned previously, it cannot with certainty be said how the collection of Micah's oracles or related oracles came about. With Micah 7:8-20 as the concluding section of the book, one is left with a sense of well-roundedness, of completeness. The collection of oracles attributed to Micah in general has a sombre tone. For this very reason Micah 7:8-20 seems to change the mood. It breathes hope into a negative atmosphere of judgment. The confessional nature of this ending help in bringing an understanding of the purpose of this section. It serves no purpose to any community, at any point in time, to hear only judgment and condemnation. Mere judgment is futile without creating a sense of hope and restoration for the faithful few who respond positively to the oracles of warning directed at the people.

The message of Micah 7:8-20 is that there is hope and a future for Yahweh's people. He is the hope and the future. Therefore this sections seems to be an apt conclusion to the book of Micah.

\section{Consulted literature}

Alfaro, J I 1989. Micah. Justice and loyalty. Grand Rapids: Eerdmans (ITC).

Allen, L C 1976. The books of Joel, Obadiah, Jonah and Micah. Grand Rapids: Eerdmans (NIC). 
Andersen, F I \& Freedman, D N 2000. Micah. New York: Doubleday (The Anchor Bible).

Cuffey, K H 1978. The coherence of Micah: A review of proposals and a new interpretation. D.Phil dissertation. Madison, New Jersey: Drew University.

Gerstenberger, E 1977. "Psalms", in: Hayes, J H (ed), Old Testament Form Criticism. San Antonio, Texas: Trinity University Press.

Gowan, D E 1998. Theology of the prophetic books. The death and resurrection of Israel. Louisville, Kentucky:Westminster John Knox.

Hagstrom, D G 1988. The coherence of the book of Micah. A literary analysis. Atlanta: Scholars Press.

Hillers, D R 1984. Micah. Philadelphia: Fortress (Hermeneia).

Mason, R 1991. Micah, Nahum, Obadiah. Sheffield: JSOT.

Mays, J L 1976. Micah. London: SCM (OTL).

McKane, W 1998. Micah. Introduction and Commentary. Edinburgh: T \& T Clark.

Schuman, N A 1989. Micah. Kampen: Kok.

Shaw, C S 1993. The speeches of Micah. A rhetorical-historical analysis. Sheffield: JSOT.

Zondervan The New International Version, 1994. Grand Rapids, MI: Publishing House.

Wessels, W J 1998. Micah1, an apt introduction to power talks. Skrif en Kerk 19(2), 438-448. 